\title{
TOPLUMSAL AIDIYET KAPSAMINDA BENIMSENMIŞ VE KIMLIK TEMSILi SORUMLULUĞUNU ÜSTLENMIŞ GÖRSEL GÖSTERGELER
}

\author{
Visual Signs which are adopted within the Scope of Social Belonging and \\ which have the Responsibility for the Representation of Identity
}

\section{Nagihan ÇETIN*}

\section{öz}

Doğduğu andan itibaren ait olma içgüdüsünden hareketle başta annesine ait olmak ve annesini sahiplenmek isteyen birey, yaşamı boyunca bu ait olma ve sahiplenme hissiyle hareket etmekte; bireysel ölçüde başlayan bu hisler zamanla toplumsallaşmakta ve toplumlar hem kendilerini ait hissetmek hem de kendilerine ait olanı hissettirmek amacıyla görsel göstergeler kullanmaktadırlar. Bilgi ve iletileri dil kullanmadan aktararak, gösterileni temsil eden görsel araçlar olarak tanımlanabilen görsel göstergeler, kimlik temsillerinde önemli işlevler yüklenmektedirler. Bu çalışmanın kapsamı, görsel göstergeler olarak niteleyebileceğimiz Türk halk resmi örneklerinin aidiyet ve kimlik bağlamında yer kimliği oluşumunda yüklenmiş oldukları sorumlulukların cemevleri merkezli olarak Karacaahmet Cemevi örneğinden hareketle incelenip değerlendirilmesidir. Çalışma neticesinde elde edilen bilgiler Türk halk resminin, görsel göstergeler olarak işlevlerinin var olduğunun ve devam ettiğinin somut bir göstergesi şeklinde yorumlanmıştır. Çalışma resim analizine dayanmaktadır. Resimlerin sadece bir tablo olarak süsleme işlevini yerine getirmekle kalmayıp menkıbeden dünya görüşüne, düşünce yapısından inanışlara varıncaya kadar birçok konuya ilişkin atıflar, hatırlatmalar, göndermeler taşıdıkları görülmüştür.

Anahtar Sözcükler: Aidiyet, Kimlik, Yer Kimliği, Görsel Gösterge, Cemevi. \section{ABSTRACT}

The individual who firstly wants to belong to the mother and embrace her due to the instinct of belonging, which occurs from the moment of birth, acts with a sense of belonging and ownership throughout the life. These emotions which emerge at the individual level become social phenomena in time. Thus, societies use visual signs to feel the sense of belonging and to feel the thing which belongs to them. Visual signs which extracts information and messages without language and which can be defined as visual tools, which represent the signified, have important functions in the representations of identity. Within the scope of this study, the role of the exam-

\footnotetext{
* Dr. Öğr. Üyesi. Antalya AKEV Üniversitesi, Insani Bilimler Fakültesi, Türk Dili ve Edebiyatı Bölümü, Antalya/Türkiye. E-posta: nagihan.cetin@akev.edu.tr. ORCID ID: 0000-0001-5098-2573. 
ples of Turkish folk paintings which can be described as visual signs was evaluated in the context of belonging and identity in the development of the place identity. Hence, examples of cemevis, especially Karacaahmet Cemevi, were examined. As a result of the study, revealed information is interpreted as that Turkish folk painting have functions as visual signs and their functions still continue. The study is based on picture analysis. It has been observed that the paintings not only fulfill the ornamental function as a painting, but also contain references, reminders, and references to many subjects ranging from legend to world view, from mentality to beliefs.

Keywords: belonging, identity, place identity, visual sign, Cemevi.

\section{Giriş}

Temsil misyonunu üstlenmiş görsel göstergelerin etkinliği, mevcut kültürel kodlar üzerinden gelişim sürecini tamamlamış olduğunda, hedef kitlenin olası direncini kırma avantajıyla iletişim süreci güçlendirilmiş olur. Bu süreçte hedeflenen anlamsal yoğunluk, ancak görsel göstergelerin uzlaşımsal bir anlayışla kabul görmesi halinde gerçekleşir. Uzlaşımsal anlayışla edimsel olarak kazanılan öğrenilmişlikler, kültür üyeleri arasında yürütülen iletişimde yazılı olarak ifade edilmeden görsel göstergeler aracılığıyla aktarılarak göstergenin nesnesi üzerindeki temsili kuvvetlendirir ve kültür topluluğu içerisindeki simgesel ilişki toplumsal işleve dönüşür.

Görsel göstergelerin üstlenmiş oldukları bu toplumsal işlevler aidiyet, kimlik ve yer kimliği açılarından incelenebilir. Bu bağlamda çalışmanın kapsamı, görsel göstergeler olarak nitelenebilen Türk halk resmi örneklerinin aidiyet ve kimlik bağlamında yer kimliği oluşumunda yüklenmiş oldukları sorumlulukların cemevleri merkezli olarak Karacaahmet Cemevi örneğinden hareketle incelenip değerlendirilmesi ile sınırlıdır. Çalışmanın zeminini daha sağlam bir şekilde kurabilmek için görsel göstergeler ve bunların üstlendiği işlevler üzerine yapılmış olan çalışmaların içeriğinden ana hatlarıyla bahsetmek yerinde olacaktır. Yapılan çalışmaların bir kısmında görsel göstergebilimin ne olduğu, teorik çerçevesi ve işlevlerine odaklanılmışken bir kısmında ise analizlere yer verilmiştir. ${ }^{1}$ Analizler çoğunlukla sinema filmleri,

\footnotetext{
${ }^{1}$ Birkaç çalışmayla örnek vermek gerekirse V. Doğan Günay ve Alev F. Parsa editörlüğünde hazırlanmış olan kitapta (2012) görsel göstergebilim kavramının ne olduğu, teorik çerçevesi ve işlevlerinin yanı sıra reklam, sinema, dizi, müzayede gibi örnek analiz çalışmaları yer almaktadır. Seyide Parsa'nın makalesi (1999) ise dizi, film, reklam, haber gibi birçok alanda yayın yapan televizyon içeriklerinin göstergebilim ile çözümlenebilirliğine yöneliktir. Banu Başkan Karsak'ın çalışmasında (2004) bir firmanın web sayfasındaki görselleri değerlendirmiştir.
} 
diziler, reklamlar, fotoğraflar, resimler ve afişler üzerinedir. Bahse konu çalışmalar büyük oranda iletişim, dilbilim, radyo televizyon ve sinema gibi alanlarda yapılmıştır. Bu çalışmada ise halk bilimi merkezli olarak Türk halk resminin tanım, kapsam ve sınırlarına odaklanılması, cemevindeki görsellerin Türk halk resminin bir parçası olduğu fikri ve bu fikrin gerekçelerinin açıklanması, söz konusu resimlerin birer görsel gösterge olarak ele alınıp göstergebilim yöntemiyle aidiyet, kimlik ve yer kimliği bağlamında değerlendirilmesi çalışmanın taşıdığı öneme ilişkindir.

\section{Yöntem}

Bireyin karşısındaki ile iletişim kurmada kullandığı araçlar sadece yazılı ve sözlü değildir. Renkler, tonlar, semboller, motifler, jest ve mimikler ile bedenin tüm hareketleri, müzik gibi unsurlar da iletişim aracı olabilmekte ve iletişim sürecinde yer alan bu unsurlar tek bir anlam ve işleve sahip olmayıp kendileri dışındaki birçok şeyin de temsili olma işlevini üstlenebilmektedirler. iletişim sürecindeki bu temsile odaklanan "göstergebilimsel çözümlemeyi Saussure 1915 yılında yayınlanan Genel Dilbilim Dersleri adlı yapıtında savunur. Saussure bu çalışmada göstergelere uygulanabilen kavramlardan söz eder" (Başkan Karsak, 2004: 102). Gösterge ise "kendi dışında bir şeyi temsil eden ve dolayısıyla bu temsil ettiği şeyin yerini alabilecek nitelikte olan her çeşit biçim, nesne, olgu vb. olarak tanımlanır. Dolayısıyla sözcükler, simgeler, işaretler vb. gösterge olarak kabul edilir" (Rifat, 2014: 11). Barthes, göstergenin bir gösteren ve bir gösterilenden kurulu olduğunu ve gösterenler düzleminin anlatım düzlemini gösterilenler düzleminin ise içerik düzlemini oluşturduğunu söyler (1993: 47). Barthes,

göstergebilimin konusunun anlam olduğunu kesinleyerek tüm gösterge dizgelerinin, örneğin resimlerin, yazım yapıtlarının, tiyatronun vb. birer anlam dizgesi oluşturduğunu söyler. Barthes, "Rhetorique de l'image" adlı makalesinde dilsel iletinin yanında, ikonografik ya da düzanlamsal ve simgesel ya da yananlamsal iletinin incelenmesi üzerinde durur (Başkan Karsak, 2004: 102).

Düz anlam mesajı, ilk karşılaştığımızda gördüğümüz ögeler, yani gördüklerimizin biz yorum yapmadan taşıdıkları anlamlarken biz, düz anlam mesajları üzerine yorumlar yaparak yan anlam mesajlarını oluştururuz. Çift başlı bir kılıç görseli gördüğümüzde bizdeki ilk anlamı yani düz anlamı, kılıç iken; bilgi birikimimiz, hayal gücümüz, aldığımız eğitim, içerisinde yaşadığımız toplum ve taşıdığımız kültürel kodlar gibi değişkenlere dayalı olarak bu kılıç görseline Hz. Ali'nin kılıcı, İslamiyet, Ehl-i Beyt, yiğitlik, adalet, 
cengâverlik gibi yan anlamlar yükleriz. Bu çalışmada da incelenen Karacaahmet Cemevi'nden seçilen örnek görsel göstergeler taşıdıkları düz anlam ve yan anlamlar üzerinden aidiyet ve kimlik bağlamında değerlendirilecektir. Çünkü "görsel ögeler, kullanılan imgelerle gösterdiğinin yanında göstermek istediği ile de işlevi olan anlatım türleridir" (Günay, 2002: 159). Sosyal bilimler alanında kullanılabilecek birçok yöntemden göstergebilimin seçilmesi, cemevinde kullanılan resimlerin sadece birer resim olarak kullanılmadığının görsel göstergeler olarak aidiyet, kimlik, benimseme, temsil, ayırt etme, yansıtma gibi birçok işlevi bünyelerinde barındırdığının düşünülmesindendir. Çalışmada resimler gösteren, gösterilen ve gösterge olarak incelenerek taşıdıkları düz ve yan anlamlar irdelenecektir. Bu çalışmada kullanılan görseller, Karacaahmet Cemevi yönetiminden yazılı izin alınarak tarafımca çekilmiş fotoğraflardır.

\section{Aidiyet, Kimlik, Yer Kimliği}

Sosyal bir varlık olan insana ait özellikler ile birinin, belirli bir kimse olmasını niteleyen sıfatların bütünü olarak tanımlanabilen "kimlik" terimi, Latince kökenlidir. "Sen kimsin?" ya da "ben kimim?" sorularına yanıt olarak verilebilen her söylem aslında bir kimlik açıklamasıdır. "Sosyal bilimlerde 1950'li yıllardan itibaren yoğun olarak kullanılmaya başlanan kimlik kavramı, temelde birey ile toplum arasındaki ilişkiyi açıklar ve 'Ben kimim?', 'Ben nereye aitim?' gibi soruların cevaplarıyla bağlantılıdır” (Dalbay, 2018: 162 163). Kimlik, mensup olunan aile, cinsiyet ya da ırk gibi özelliklerin doğuştan kazanılmasının yanında, büyük oranda inşa edilen bir niteliğe sahiptir. Kimlik inşasının iki boyutu vardır; bireysel veya öznel kimliğin inşası ve kolektif veya sosyal kimlik inşası (Gözübüyük Tamer, 2014: 92). Kimliğin inşasına yönelik olan bu kimlik türlerinden kolektif kimlik, semboller, anılar, sanat eserleri, değerler, inançlar gibi geleneğin bilgisiyle yüklü unsurları yani toplumsal bir birikimi ifade etmektedir (Dalbay, 2018: 170). Bireylerin kolektif kimlikten beslenerek kendi kimliklerini oluşturma süreçlerinin, kendi aidiyetlerini de bu kimlikler üzerinden tanımlamaları şeklinde bir sonuç ortaya çıkarması, kimliğin inşasının, aidiyet kavramı ile girift bir yapı sergilediğini söylemeyi mümkün hale getirmektedir.

Kimlik kavramı, "aidiyet” kavramı ile bütünleşik bir yapıya sahiptir. Bireyin kim olduğu sorulduğunda verdiği yanıtlar asında onun aile, ırk, din, ideoloji, meslek, coğrafya, devlet gibi bireyselden öte toplumsal bağlamı olan yanıtlardır. Buna istinaden kimlik inşa sürecinin bireysel olduğu kadar, belki de ondan daha etkin olarak kolektif kimliğe dayalı olduğunu söylemek mümkündür. 
Aidiyet ise bireyin kimliğinin oluşumunda etkin olan ve özellikle kolektif kimliğin şekillenmesinde yer alan bir duygudur. Aidiyet duygusu, insanın temel ihtiyaçlarından birini oluşturur (Şentürk ve Gülersoy, 2019: 146). Bu intiyaç karşılanmadığında bireylerin içinde bulundukları toplum ve bu toplumun değerleri ile ilişkileri zayıflayabilir yahut olumsuz çağrışımlı toplumsal davranışlara, örneğin çatışma ve sapmalara zemin hazırlayabilirler.

insanların içerisine doğup, içerisinde yetiştiği ve kolektif kimliğin ayrılmaz bir parçası olan, aynı zamanda aidiyeti şekillendiren ve anlamların belirlenmesinde büyük bir rolü olan kültür de onların "ben kimim?" sorusuna verdikleri cevaplardandır. Kültür dairesinin içerisinde yer alan bütün kurumlara birlikte veya ayrı ayrı bir bağlılık yahut tersiyle, bunlardan kopma, kaçınma gibi davranışlar, bireyin kim olduğunun tanımlanmasında önem arz eder. Zira kim olduğumuz sorusunun cevabı çoğunlukla "kim olmadığımızı" da tanımlar ve aidiyet, içerisinde "diğerlerinden ayrılmayı" da barındıır. Bazı bireyler, içinde yer aldıkları toplum veya topluluğun belirli bir kültürel değerini benimserken diğerine karşı aynı derecede bağlılık taşımayabilirler. Ancak bu durum, ait olunan kültürel kurumların her biri, her birey için aynı önemi taşımasa bile, herhangi birini önemsiz hale de getirmez; bireyde aidiyeti oluşturan unsurların her biri, kendine özgü bir değer taşır (Gözübüyük Tamer, 2014: 85).

Aidiyet ile yakından ilişkisi olan bir diğer kavram ise "mekân"dır. Mekânın aidiyet ile arasındaki güçlü bağın doğrusal bir ilişki olduğu yönünde hâkim bir görüş vardır ve bu görüş özellikle 1970’li yıllardan sonra sıklıkla ifade edilir olmuştur. Aidiyet kavramının fiziki mekândan bağımsız şekilde değerlendirilmesi ve bu değerlendirmenin sadece bireyin algısı üzerinden tanımlanması, bir eleştiri noktası hâline gelmiştir. Böylece aidiyetin oluşabilmesi için öncelikle ait olunan bir yerin gerekli olduğu, bu yerlerin de bireysel ve mekânsal aidiyetin kurulmasındaki etkisine dikkat çekilmiştir (Şentürk ve Gülersoy, 2019: 146). Söz konusu mekânsal aidiyet, mekâna bir kimlik yüklemeyi de beraberinde getirmektedir. Toplumlar, üzerinde yahut içerisinde yaşamış oldukları mekânlarla da ilişki içerisinde bulunmuşlar, bu ilişkiler dâhilinde mekânlara da anlamlar vermişlerdir. Yaşadıkları yerlerin coğrafi şekilleri sporlarını, iklimi mutfaklarını, kaynakları mesleklerini belirlemiş; bu mekânlarda biriktirdikleri tüm tecrübeleri ise onların hafızasını oluşturmuştur. Toplumlar ve mekânlar arasındaki bu ilişki, onların gerek öznel gerekse de kolektif kimliğin inşasında ne derece önemli olduğunu göstermektedir. 
Proshansky, mekâna bağlı deneyimleri kimlik ile birleştirip bu ilişkiyi "yer kimliği” olarak kavramsallaştırarak insanın doğal ve yapılandırılmış çevreyle, fiziksel dünyayla ve başka insanlarla ilişkilerinde tercihleri, beklentileri, duyguları, değerleri ve inançları tarafından belirlenen, yerin ve kişinin kimliğini yapısında birleştiren karmaşık bir örüntü olarak açıklamıştır (akt. Turut ve Özgür, 2018: 159). Aidiyet, bireysel işlevlerinin yanında toplumsal işlevler de yüklenerek "yer"in değer kazanması ile toplumun belirli düşünce ve duygularda birleşmesine de katkı sunmaktadır. Birey ve/veya topluluklar, aidiyet hissettikleri mekânları şekillendirirler, oradan ayrılmak istemezler yahut onu korurlar. Yer kimliğinin tanımı, bireysel kimliğin bilinçli ya da bilinçsiz olarak fiziksel çevreyle ilişkilendirilmesini içine alır. Bu ilişkiler, fikirleri, duyguları, inançları, değerleri, hedefleri ve davranışları kapsar. Yer kimliğinin öğeleri, bireysel ve kolektif anlamlar ve semboller ile açıklanır ve kimliğin ayırt edicilik, süreklilik, yararlı olma gibi prensiplerini de taşırlar. Bunlarla birlikte yer kimliği, aidiyetin fiziksel bağlamını oluşturur (Şentürk ve Gülersoy, 2019: 147).

Mekânın değişmesi, bu mekâna bağlı inşa edilen yer kimliğini ve dolayısıyla onun aracılığıyla oluşturulan bireysel ve kolektif kimlikleri de değiştirir. Ancak mekân değişimi sadece fiziksel bir değişime işaret etmez, mekânların zamansal olarak yaşadıkları değişimler de bu kapsamda değerlendirilmelidir. Zamansal değişimlerin içerisinde coğrafyada yaşanan doğal farklılılar yer alabileceği gibi, insanların yaşadıkları çağın gerekliliğine uygun olarak yaşam alanlarını geliştirmeleri ve ona tekrar tekrar şekil vermeleri söz konusudur. Bu da bizi, değişim sürecinde mekân algısının ve yer kimliğinin zamansal boyutuna yönlendirir ve bazı durumlarda süreç, mekân ile toplumlar arasındaki ilişkinin niteliği ve sürekliliğinde dönüşümlere yahut kopmalara yol açabilir.

Özgüleş, kimlik inşasında mekân, zaman ve toplumlar arasındaki sürekliliğin kopma noktalarını, modern dönemlerde yaşayan insanların aidiyet hissinde yaşadığı bocalamalarla birlikte açıklamaktadır. Ona göre insanların giderek aidiyetsizlik hissi ile çevrelenmeleri, yaşadıkları mekânları seçtikleri yeni kimliklere göre dönüştürme biçimleri ve intiyaçları doğrultusunda aidiyet hissedebilmek için yeni baştan kurdukları mekânlar ile yakından ilgilidir:

Bu mekânların tümü kendini dış dünyadan soyutlayan, çevresine keskin sınırlar çizen, yumuşak geçişlere izin vermeyen kapalı mekânlardır. Bir şehrin surlarından tutun bir külliyenin dış duvarlarına kadar; dikenli teller ve kameralarla çevrelenmiş konsolosluk 
binalarından stadyumlara kadar geniş bir tarihsel, sosyolojik ve kültürel yelpazeye yayılan bu mekânlar, ait olunanın simgesel bir özetini de teşkil ederler (Özgüleş, 2019: 34).

Dini bir toplumsal yapı olan Alevi toplumunun ibadethanesi olarak tanımlanabilen cemevleri de Alevilerin kendilerini ait hissettikleri, kendi kimlikleri üzerinden yer kimliği kazandırdıkları mekânlardır ve bu mekânların inşasında ve diğer mekânlardan ayrılmalarında görsel göstergeler önemli işlevler yüklenmiştir. Çalışmanın bundan sonraki kısmında Karacaahmet Cemevi'nde yer alan görsel göstergelerden hareketle cemevlerinin kimlik kazanması ve kimlikleri yansıtmaları ile bireylerin kendilerini bu mekânlara ait hissetmelerinde görsel göstergelerin işlevleri ve anlamlarına odaklanılarak değerlendirmelerde bulunulacaktır.

\section{Cemevleri ve Karacaahmet Cemevi}

Alevilerin bir araya geldikleri yerler olan cemevlerinin ${ }^{2}$ ilk nerede ve ne zaman açıldığı konusunda farklı görüşler bulunmaktadır. ${ }^{3}$ Karacaahmet Cemevi, 1969 yılında kurulmuş olan "Karacaahmet Sultan Türbesini Onarma ve Yaşatma Derneği” bünyesinde hizmet vermektedir. Karacaahmet Sultan Dergâhı, Osmanlı Devleti döneminden kalan ve günümüzde de faal olmayı sürdüren bir dergâhtır. Dergâhın kurucusu olan Karacaahmet Sultan, 13. yüzyılda yaşayan Horasan erenlerinden biri olarak anılmaktadır. Karacaahmet'in Alevi Bektaşi öğretisinin yayılması için Batı Anadolu başta olmak üzere birçok yerde çalışmalar yaptığı da bilinmektedir (Kocadağ, 1998: 246). Hacı Bektaş Veli'ye bağlı olan Karacaahmet Sultan, onun tarafından Horasan erenlerini örgütlemek için, "gözcü" sıfatıyla istanbul'a gönderilmiştir. Karacaahmet Sultan'ın yaşadığı dönemde Üsküdar'da kurulan bu dergâh, Hacı Bektaş Veli felsefesini yaymanın yanı sıra, ruh hastalıklarını tedavi için de önemli bir merkez kabul edilmektedir. Uzun bir süre boyunca türbe olarak hizmet veren bu yapı, Yeniçeri Ocağı'nın kaldırıldığı Vakay-ı Hayriye (1826) döneminde kapatılmıştır. Daha sonra II. Meşrutiyet'te yeniden açılmış, Cumhuriyet dönemine kadar hizmet vermeye devam etmiş ve nihayetinde "Tekke, Zaviye ve Türbelerin Kapatılması Kanunu" ile 1925 yılında yeniden kapatılmıştır (Yılmaz, 2011: 106).

\footnotetext{
${ }^{2}$ Cemevlerinin statüsü hakkında farklı görüşler vardır. Genel olarak Alevi vatandaşlar cemevlerinin ibadethane olduğunu belirtirken, resmi kurumlar ve çoğunlukla Sünni vatandaşlar cemevlerinin ibadethaneden ziyade kültürel mekânlar olduğu görüşündedir. Bu konuda bk. (Yıldırım, 2018).

${ }^{3}$ Bu konuda geniş bilgi için bk. (Rençber, 2012).
} 
1969 yılında ise Güllü Ana'nın öncülüğünde dergâh tekrar aktif hâle getirilmiştir. Bu aktifleşme sürecinde dergâhın statüsü, önce dernek sonra vakıf olarak değiştirilmiştir. 1990'lı yıllarda ise vakıf bünyesinde bir cemevi açılması gündeme gelmiş, inşaata başlanmış fakat süreç resmi olarak tamamlanamamış ama cemevi faaliyetlerine başlamıştır. Kurumsal web sayfasında yer alan bilgilere göre dergâh 1969 yılında tüm organlarını oluşturarak kurulan ilk Alevi derneğidir. Şükrü Alptekin tarafından kurulmuş ve yaklaşık 47 yıldır hizmet vermeye devam etmektedir. Mevcutta 40 yöneticisi, 6000 üyesi, 25 personeli ile $2.500 \mathrm{~m}^{2}$ bir alanda, haftalık 5000 ziyaretçiyi ağırlamaktadır. Bünyesinde iktisadi idari birimiyle yönetilen kütüphane, cem salonu, iki yemekhane, kurban kesim yeri, cenaze uğurlama alanı, yönetim birimleri, Alevilik hizmeti veren dede odası, derslikler, sosyal ve kültürel etkinlik alanları yer almaktadır (URL-1).

\section{Karacaahmet Cemevi'nin Görsel Göstergeler Açısından Incelenmesi}

Görsel göstergeler aidiyet, kimlik ve yer kimliğine bağlı olarak bireyin söz konusu mekâna kendini ait hissetmesini sağlama, mekânı "öteki" mekânlardan ayırma ve mekâna kimlik kazandırma gibi birçok işleve sahiptir. Bu çalışmanın örneklemini oluşturan Karacaahmet Cemevi'nde de bu işlevlere sahip olan birçok görsel gösterge bulunmaktadır. ${ }^{4}$ Cemevinin girişinden başlayarak kullanıma açık her bölümünde yer aldığı görülebilen bu göstergeler mekâna bir kimlik kazandırmakta ve söz konusu mekâna gelen bireylerin kendilerini oraya ait hissetmelerine katkı sunmaktadır. Birey mekâna ilk girişte yer bulan görselleri gördüğünde girdiği mekânın Aleviliğe ait bir mekân olduğunu fark edebilmektedir. Gezme, merak etme gibi amaçlarla mekâna gelen kişiler bir tarafa bırakıldığında mekâna gelen kişiler nereye geldiklerini bilerek, isteyerek ve gerekliliğine inanarak gelmektedirler. Gelinen mekân aynı zamanda gelenlerin kimliğini de tanımlayıcı ve tamamlayıcı bir işlev üstlenmekte ve "Ben Alevi'yim, buraya aitim, burası benim, burası benim ibadethanem" bilinci ve duygusuyla birlikte gelen kişilere manevi bir tatmin hissi yaşatmaktadır. Bu süreçte mekânda yer alan türbenin yanında görsel göstergeler etkin olarak ön plana çıkmaktadır. Çünkü mekânın kimliği bu göstergeler ile yansıtılmaktadır.

Hz. İbrahim, Hz. Ali, Hz. Hasan, Hz. Hüseyin, On İki İmam, Hacı Bektaş Veli, Pir Sultan Abdal, Mevlana, Hz. İbrahim, Zülfikar, güvercin ve aslan mekânda bulunan başlıca göstergelerdir. Resimlerin bir kısmının üzerinde ressamının imzası vardır ve bu ressamlardan kimileri yabancıdır. Cemevinde

\footnotetext{
${ }^{4}$ Cemevlerinin işlevleri hakkında geniş bilgi için bk. (Üçer, 2018).
} 
bulunan bu resimler, aynı zamanda Türk kültüründe, Türk halk resmi içerisinde de değerlendirilebilmektedir. Çünkü kimi resimleri yapanın, kimi resmi yapılanların yabancı olması ya da resmin üzerinde ressamının imzasının bulunması o resmin Türk halk resmi içerisinde değerlendirilmesine engel teşkil etmemektedir. Yukarıda ismi zikredilen kişilerin Türk kültüründe genel olarak kabul gören birer resim formu vardır ve yapılan tüm resimler bu formların yeniden yorumlanmasıdır. Haliyle kültür içerisinde bu resimlerde kimin tasvir edildiği, hangi resmin kime ait olduğu genel anlamda bilinmektedir ve bu bilinirlik sadece insan resimleriyle de sınırlı değildir; bunun en belirgin örneği ise Hz. Ali'nin kılıcı olan Zülfikâr'dır.

ilk olarak ne zaman, nerede, kim tarafından, kimin için üretildiği hususunda birçok farklı görüş olan Zülfikâr (Öz, 2013: 553), Hz. Ali'nin çift başlı olarak tanımlanan kılıcıdır. Türklerin İslamiyet ile tanışmasından itibaren zamanla bu kılıç Türk kültüründe önemli bir göstergeye dönüşmüştür. Mekân süslemelerinden kıyafetlere, kitap resimlerinden takılara birçok alanda görsel bir unsur olarak bu kılıçtan esinlenilmiştir. Örneğin "Osmanlılar'da Zülfikar motifi tezyinatta da kullanılmış, özellikle islâm resim sanatının en önemli kısmını teşkil eden kitap resimlerinde $\mathrm{Hz}$. Ali daima elinde veya belinde Zülfikar'la, Kanber ve düldülle tasvir edilmiş, dinî resimlerde de Ali'ye ve Zülfikar'a çeşitli hat kompozisyonları içinde yer verilmiştir" (Sarıkaya, 2013: 556). Bugün için bu kılıç tablo olarak mekân süslemelerinin yanında özellikle kolye olarak takılarda kullanılmaktadır. Karacaahmet Cemevi'ndeki birçok görselde yer alan bu kılıç gösterge olarak güç, cesaret, yiğitlik gibi birçok özelliğe atıfta bulunmaktadır.

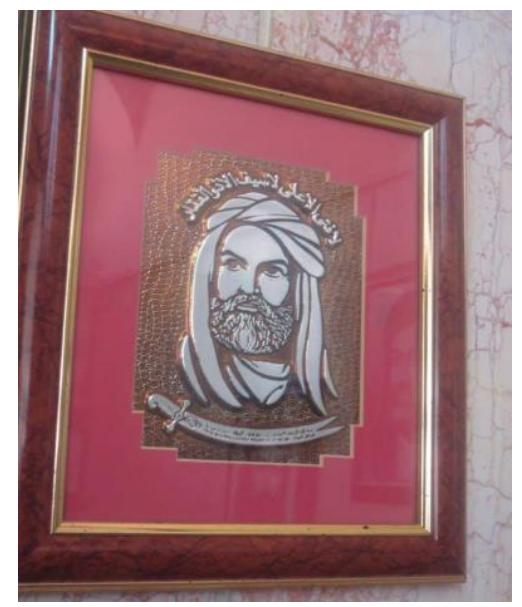

Görsel 1. (Yazar Arşivi) 


\begin{tabular}{|l|l|l|}
\hline Gösterge & Gösteren & Gösterilen \\
\hline İnsan ve kılıç & $\begin{array}{l}\text { Bir erkek resmi ve üzerinde } \\
\text { yazı olan bir kılıç }\end{array}$ & $\begin{array}{l}\text { Hz. Ali'yi kılıcı Zülfikâr ile resmederek } \\
\text { Hz. Ali'nin yiğitlik ve cesaretine vurgu } \\
\text { yapııması } \\
\text { Yazı: “Lâ fetâ illâ Alî, lâ seyfe illâ zül- } \\
\text { fikār” (Ali'den başka yiğit, zülfikardan } \\
\text { başka kılıç yoktur) }\end{array}$ \\
\hline Düz Anlam & \begin{tabular}{l} 
Yan Anlam \\
\hline $\begin{array}{l}\text { Kompozisyonunda bir insan, yazı ve kılıç } \\
\text { olan bir tablo }\end{array}$
\end{tabular} & $\begin{array}{l}\text { Hz Ali'nin yiğitliği cesareti ve Zül- } \\
\text { fikâr'ın özelliği }\end{array}$ \\
\hline
\end{tabular}

Cemevindeki resimlerin çoğunluğunda kırmızı ve yeşil renkleri hâkimdir. Renkler göstergebilimde, bireye çağrıştırdıkları anlamlar ile bireyin psikolojisi üzerinde yarattıkları etki ve çağrışım yapmış oldukları olay ve hisler açısından önemli olan göstergelerdir. Cemevinde yer alan resimlerde kullanılan renkler işaret ettikleri kültürel olaylar sebebiyle farklı anlamlara sahiplerdir. "Alevi-Bektaşi kültüründe renklerin özel anlamları vardır. Bu cümleden olarak, beyaz Hz. Muhammed'e, kırmızı Hz. Ali ve Hz. Hüseyin'e, açık yeşil ve sarı $\mathrm{Hz}$. Hasan'a, pembe ve yeşil $\mathrm{Hz}$. Hüseyin'e, kara/siyah ise $\mathrm{Hz}$. Fatıma'ya yakıştıııı’" (Günşen, 2007: 34).

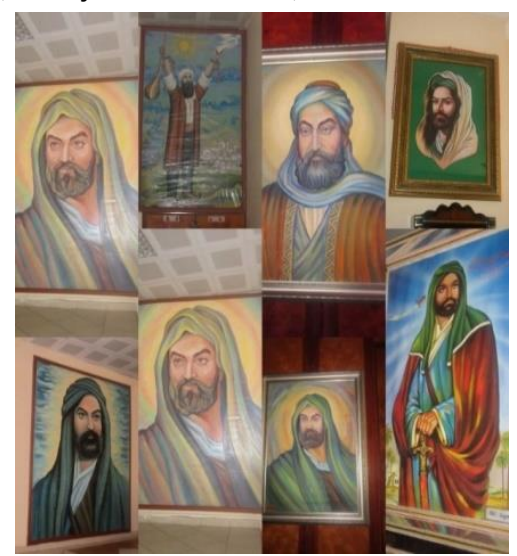

Görsel 2. (Yazar Arşivi)

\begin{tabular}{|l|l|l|}
\hline Gösterge & Gösteren & Gösterilen \\
\hline insan & $\begin{array}{l}\text { Yeşil ve kırmızı renklerde } \\
\text { giyimli insan }\end{array}$ & $\begin{array}{l}\text { Hz. Hasan'ın zehirlenerek, Hz. Hüse- } \\
\text { yin'in kanı akıtılarak şehit edilmesi }\end{array}$ \\
\hline Düz Anlam & Yan Anlam \\
\hline $\begin{array}{l}\text { Yeşil ve kırmızı renklerde örtü ve cübbe } \\
\text { giyinmiş insanlar }\end{array}$ & $\begin{array}{l}\text { Hz. Hasan ve Hz. Hüseyin'in şehit edil- } \\
\text { melerine telmih }\end{array}$ \\
\hline
\end{tabular}


Cemevindeki bir diğer görsel gösterge Hz. İbrahim'le ilgilidir. İslamiyet'te ilk kurbanın ortaya çıkışı Hz. İbrahim'e dayandırılmaktadır. Kur'an-ı Kerim'de anlatıldığına göre Hz. İbrahim, Allah'a bir oğlu olması halinde onu kendisine kurban edeceğine dair ant içer ve bir oğlu olur. Hz. İbrahim sözünü tutmak için oğlu ismail'i kurban edeceği sırada Cebrail gökten bir koç getirerek Allah'ın ibrahim'den İsmail'i bırakıp bu koçu kurban etmesini istediğini söyler ve Hz. İbrahim de koçu kurban eder. Bu kıssa kulun Allah'a sadakatine ve Allah'ın da kulunu zorda bırakmayacağı inancına bir örnek olması sebebiyle nasihat amaçlı olarak sözlü kültür içerisinde dile getirilir ve Türk halk resmi örneklerinde de tasvir edilir. Cemevindeki $\mathrm{Hz}$. Ibrahim tasviri de bu kıssayı hatırlatmaktadır.

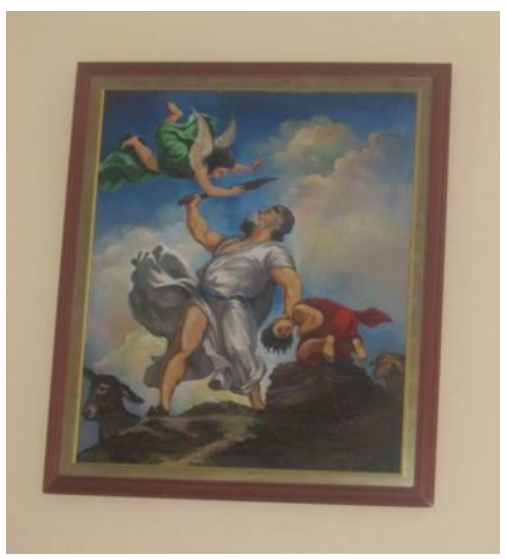

Görsel 3. (Yazar Arşivi)

\begin{tabular}{|c|c|c|}
\hline Gösterge & Gösteren & Gösterilen \\
\hline İnsan & $\begin{array}{l}\text { Bir çocuğu boynundan eğ- } \\
\text { miş, bir elinde bıçak olan } \\
\text { erkek }\end{array}$ & $\begin{array}{l}\text { Hz. Ibrahim'in Allah'a verdiği sözü } \\
\text { tutmak için oğlunu kurban etmeye } \\
\text { kalkışması }\end{array}$ \\
\hline Çocuk & $\begin{array}{l}\text { Bir erkek tarafından boy- } \\
\text { nundan tutularak eğilmiş } \\
\text { bir çocuk }\end{array}$ & $\begin{array}{l}\text { İsmail'’in, babasının sözünü tutması } \\
\text { için sakin bir şekilde kurban edilmeyi } \\
\text { beklemesi }\end{array}$ \\
\hline Melek & $\begin{array}{l}\text { Gökten kanatlı ve yeşil elbi- } \\
\text { sesiyle uçarak gelen bir } \\
\text { melek }\end{array}$ & $\begin{array}{l}\text { Allah'ın kuluna yardımını göstermek } \\
\text { için gökten bir meleğin çocuğun yerine } \\
\text { kurban edilmesi için bir koç getirmesi }\end{array}$ \\
\hline \multicolumn{2}{|c|}{ Düz Anlam } & Yan Anlam \\
\hline \multicolumn{2}{|c|}{$\begin{array}{l}\text { Oğlunu kesmeye çalışan ibrahim'in melek } \\
\text { tarafından engellenmesi }\end{array}$} & $\begin{array}{l}\text { Kul olarak Allah'a verdiği sözü tutma- } \\
\text { ya çalışan ibrahim'e Allah'ın bir kolay- } \\
\text { lık göstermesi, ona yardım etmesi }\end{array}$ \\
\hline
\end{tabular}


Cemevindeki resimler hayvan figürleri bakımından da önem arz etmektedir. Bu resimlerde aslan, koç, güvercin figürleri yer almaktadır. Güvercin, Alevi Bektaşi kültüründe, barışın ve mazlumun simgesidir. Bilindiği gibi "Incinsen de incitme", "Düşmanının bile insan olduğunu unutma" diyen $\mathrm{Hacı}$ Bektaş Veli'nin Anadolu'ya "güvercin donunda" geldiğine inanılır (Günşen, 2007: 347).

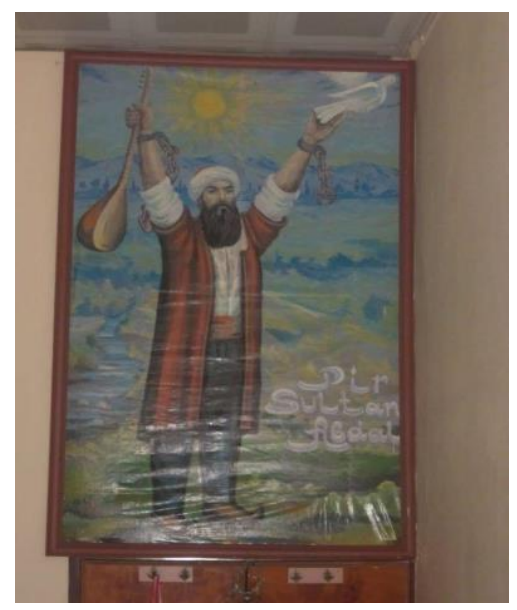

Görsel 4. (Yazar Arşivi)

\begin{tabular}{|c|c|c|}
\hline Gösterge & Gösteren & Gösterilen \\
\hline İnsan & $\begin{array}{l}\text { Kollarında kırılmış zincirler } \\
\text { bulunan bir elinde bağla- } \\
\text { ma, diğer elinde serbest } \\
\text { bıraktığı güvercinle üzerin- } \\
\text { de güneş parlayan bir insan }\end{array}$ & $\begin{array}{l}\text { Pir Sultan Abdal'ın zindanlara atılma- } \\
\text { sına atıfta bulunularak onun zincirleri- } \\
\text { ni kırıp özgürlüğe kavuştuğu mesajı }\end{array}$ \\
\hline Güvercin & $\begin{array}{l}\text { Kollarında koparılmış zin- } \\
\text { cirler olan bir insan tarafın- } \\
\text { dan serbest bırakılan bir } \\
\text { güvercin }\end{array}$ & $\begin{array}{l}\text { Pir Sultan Abdal'ın kendi zincirlerini } \\
\text { kopararak özgürlüğüne kavuşmasının } \\
\text { yanında güvercini de özgürlüğüne } \\
\text { kavuşturması }\end{array}$ \\
\hline \multicolumn{2}{|r|}{ Düz Anlam } & Yan Anlam \\
\hline \multicolumn{2}{|c|}{$\begin{array}{l}\text { Elinde bağlama olan bir insanın ellerini } \\
\text { havaya kaldırması }\end{array}$} & $\begin{array}{l}\text { Pir Sultan Abdal'ın zincirlerini kırarak } \\
\text { hem kendini hem güvercini özgürlüğe } \\
\text { kavuşturması }\end{array}$ \\
\hline
\end{tabular}

Arslan, Alevi-Bektaşi kültüründe, yiğitlik, mertlik ve cesaret timsali Hz. Ali'nin mahlası olur ve onun yiğitlik ve mertliğini simgeler (Günşen, 2007: 347). 


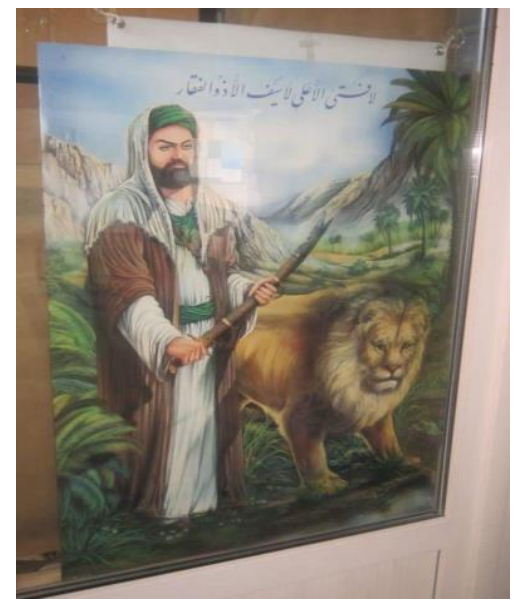

Görsel 5. (Yazar Arşivi)

\begin{tabular}{|l|l|l|}
\hline Gösterge & Gösteren & Gösterilen \\
\hline İnsan & Elinde kılıcıyla bir insan & $\begin{array}{l}\text { Elinde Zülfikârla aslanın yanında } \\
\text { korkmadan, cesaretle duran Hz.Ali. }\end{array}$ \\
\hline Aslan & $\begin{array}{l}\text { Bir insanın yanında ona zarar } \\
\text { vermeden duran aslan }\end{array}$ & Aslan'ın Hz. Ali'ye tabiiyeti \\
\hline Düz Anlam & Yan Anlam \\
\hline Bir insan aslanla yan yana. & $\begin{array}{l}\text { Hz. Ali'nin aslana teşbih edilmesi, Hz. } \\
\text { Ali'nin yiğitliğine, cesaretine vurgu } \\
\text { yapılması }\end{array}$ \\
\hline
\end{tabular}

Bilindiği gibi genel olarak İslamiyet'te var olduğu kabul edilen resim yasağından dolayı insan suretlerinin yapılmasına hele ki bunların ibadethanelerde kullanımına hoş bakılmadığı dönemlerde yazı resim tekniği gelişmiş ve özellikle mekân süslemelerinde ve mekâna kimlik kazandırma girişimlerinde yazı-resim örnekleri kullanılmıştır. Bu örnekler çoğunlukla tekkeler, Bektaşi dergâhları ve Mevlevihanelerde yer almaktadır. Resim yasağının İslam'ın ilk dönemlerinde olduğu ve zamanla esnediği bilinmesine rağmen yazıresimler yapılmaya ve birçok alanda kullanılmaya devam etmektedir. Duvar süslemeleri, giyim-kuşam, takı ve aksesuarlar bu alanların başında gelmektedir. Karacaahmet Cemevi'nde de insan sureti resimler çoğunlukta olsa da bunların yanı sıra yazı-resim örnekleri de yer almaktadır. 


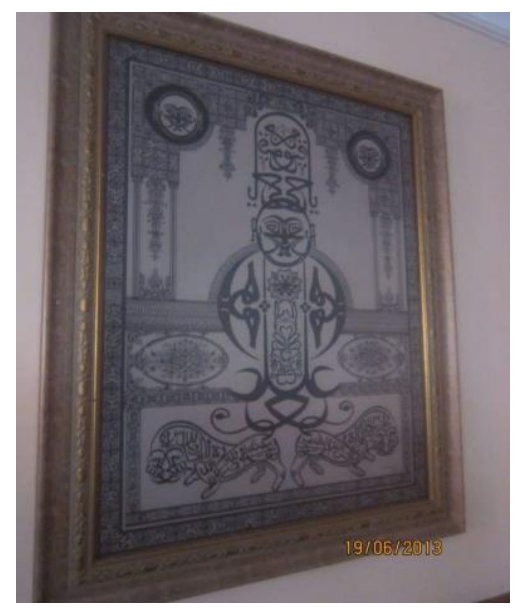

Görsel 6. (Yazar Arşivi)

\begin{tabular}{|l|l|l|}
\hline Gösterge & Gösteren & Gösterilen \\
\hline Aslan & Farklı yöne giden iki aslan & $\begin{array}{l}\text { Hz. Ali'nin Haydar'-ı Kerrar, tekrar } \\
\text { tekrar arslan; Esedullah, Allah'ın } \\
\text { arslanı olduğuna telmih }\end{array}$ \\
\hline Yazılar & $\begin{array}{l}\text { Hak, Muhammed, Ali, çifte vav } \\
\text { yazıları }\end{array}$ & $\begin{array}{l}\text { Alevilikteki Hak, Muhammed, Ali } \\
\text { üçlemesi ve Kur'an-ı Kerim'de sırrı } \\
\text { ile hikmetinin sadece Allah tarafın- } \\
\text { dan bilindiği ifade edilen harflerden } \\
\text { biri olan vav'ın Türk halk resmindeki } \\
\text { bir geleneğe uygun olarak çift şe- } \\
\text { kilde çizilmesi }\end{array}$ \\
\hline Düz Anlam & $\begin{array}{l}\text { Yan Anlam } \\
\text { Yazılar ile bir insan başı ve iki aslan şeklinde } \\
\text { oluşturulmuş bir tablo }\end{array}$ & $\begin{array}{l}\text { Hak, Muhammed, Ali üçlemesine } \\
\text { atıf ve mekânın kimliğini yansıtma }\end{array}$ \\
\hline
\end{tabular}

Buradaki yazı resim örneğinde birden fazla çifte vav, Hakk ve Ali yazımları bulunmaktadır. "Çifte karşılıklı yazıya 'hatt-ı musanna' dendiği gibi, aynalı yazı da denir. Tarikatlerde de bu çeşit yazılar çoktur. Halk arasında da sevilir, tutulur. Ayrıca tenazur, bu yazıya canlıık katar. Nitekim çifte Ali'ler bunun en güzel örneğidir" (Aksel, 2010: 110). Malik Aksel, çifte motifler dizisinin köklerinin İslamiyet öncesinde aranması gerektiğini; bu şekildeki kullanımların insan, hayvan ve bitki olarak yüz yüze, arka arkaya, yan yana dizildiklerini, daha sonra çinilerde, halılarda, yazmalarda yer aldıklarını ifade etmektedir (Aksel, 2010: 23-24).

Incelenen görselde yazı ile resim çizilmiş çifte Ali yazımıyla insan sureti oluşturulmuş, bu çizimin altına Muhammed, yan taraflarına ise "Hakk" ismi 
çift olarak yazılmıştır. Böylelikle Aleviliğin temel ifadelerinden biri olan "Hakk, Muhammed, Ali” üçlemesi yazı ile görsel bir şekilde sunulmuştur. Tablonun alt kısmında yine yazı ile farklı yönlere bakan iki aslan sureti yer almaktadır. 'Hz. Ali 'Haydar'-I Kerrar'dır, tekrar tekrar arslandır. 'Esedullah' (Allah'ın arslanı) diye türlü yazı-resimler yapılmış, buna kutsal manalar verilmiştir" (Aksel, 2010: 72).

Cemevindeki çoğunlukla suluboya, minyatür, yazı-resim, yağlıboya ve fotoğraf stüdyolarında hazırlanmış baskı örnekler bulunurken karakalem tekniğiyle yapılmış resimler de vardır.
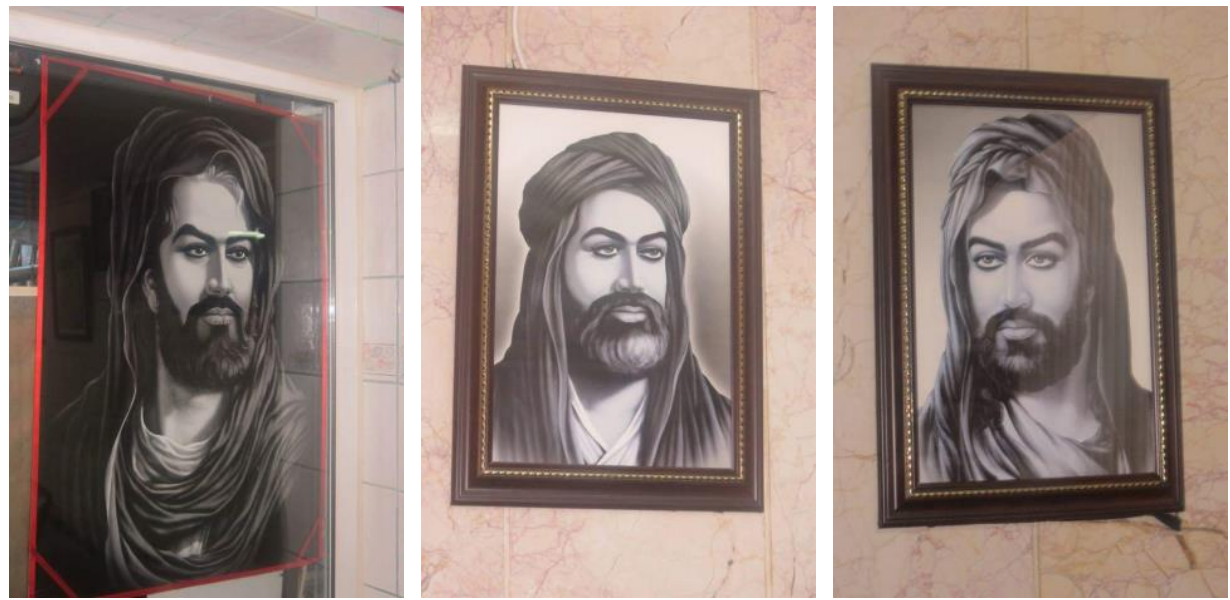

Görsel 7. Hz. Hüseyin, Hz. Ali, Hz. Hüseyin. (Yazar Arşivi)

Cemevindeki resimler erkek tasvirleridir, kadınların tasvir edildiği bir resim örneği tespit edilememiştir. Bu konuda i̇slamiyet'teki resim yasağının değil de kadının mahrem olarak kabul edilişinin etkili olduğu düşünülebilir.

\section{Sonuç}

Resim sanatı, insanın gördüğünü ya da hayal ettiğini çizgiler ya da renklerle görünür hale getirdiği bir sanat dalı olmasının yanında en gerçekçi resimler bile gerçekten çok onu çizenin gerçeği algılayışını ve bunu kendince ifade edişini içermektedir. Her resmin mutlaka bir ressamı vardır; fakat bazı resimler artık tek kişinin olmaktan çıkmış, bir halka, bir millete mal olmuşlardır; yani anonimleşmişlerdir. Bu resimler o millete ait "halk resmi" olarak adlandırılmaktadır. Türk halk resmi, modern resmin sanat eseri sayılma niteliklerinden olan özgünlük, perspektif gibi özellikleri taşımadığı gerekçesiyle eleştirilere maruz kalmasıyla birlikte kültür içerisinde birçok işlev yüklenmiş olan bir alandır. Aidiyet ve kimlik, Türk halk resminin üstlenmiş olduğu bu işlevlerin başında gelmektedir. 
Kimlik bireyin "sen kimsin ya da ben kimim" sorularına verdiği cevap iken aidiyet bireyin, "sen nereye aitsin ya da ben nereye aitim" sorularına yanıtlarıdır. Doğduğu andan itibaren tanımlanmaya başlayan ve bağlamla birlikte gerek dış etkilerle gerekse bireyin kendi tercihleri ve kişisel özellikleri ile şekillenen kimlikte bireyin aidiyet duygusu da önem taşımaktadır. Bu kimlik ve aidiyet duygusunun gelişiminde mekânlar ve mekânların sahip oldukları kimlikler etkin olarak rol almaktadır. Mekânların kimlik kazanmalarında ve kazanmış oldukları kimliği yansıtarak bireylerin aidiyet duygusuna hitap etmelerinde görsel göstergeler önemli bir unsur olarak karşımıza çıkmaktadır.

Türkiye'de Alevi vatandaşların kutsal mekânı, ibadethanesi olarak kabul edilen cemevleri, mekân kimliğine sahip olan yapılardır. Bu yapılardan istanbul'daki Karacaahmet Cemevi bu çalışmanın örneklemini oluşturmuştur. Turizm amaçlı olarak gelenler dışındaki bireyler mekâna bilinçli olarak gelmekte ve mekâna girdikleri andan itibaren mekâna kendilerini ait hissetmelerini sağlayacak birçok görselle karşılaşmaktadırlar. Bu görsellerde camaltı boyama, karakalem, minyatür, yağlı boya ve baskı gibi birçok tekniğin kullanıldığı görülmüştür. Mekândaki resimlerin bazıları yabancı ressamlar tarafından yapılmıştır ve bazılarında ressamının imzası bulunmaktadır. Söz konusu durum, bu resimlerin Türk halk resmi olarak değerlendirilmesine engel teşkil etmemektedir. Ressam yabancı da olsa, resmi yapılanların bir kısmı yabancı da olsa söz konusu resimler Türk kültüründe idealleştirilmiş bir formun yeniden yorumlarıdır. Ayrıca her resmin mutlaka bir ressamı vardır; fakat bazı resimler, resimlerde yer alan kişiler, semboller tek kişinin olmaktan çıkmış, bir halka, bir millete mal olmuşlardır; yani anonimleşmişlerdir ve bu resimler o millete ait "halk resmi" olarak adlandırılmaktadır.

incelenen resimlerde ağırlıklı olarak yeşil ve kırmızı renklerinin kullanıldığı, en fazla resmi yapılanların Hz. Ali ve Hz. Hüseyin olduğu görülmüştür. $\mathrm{Hz}$. Ali ve Hz. Hüseyin'in yanında Hz. İbrahim, On ỉki İmam, Hacı Bektaşi Veli, Pir Sultan Abdal, Mevlana, Âşık Veysel, Zülfikar, güvercin, koç ve aslan cemevinde yer alan diğer görsellerdir. Bu görsellerin bir kısmı çalışma kapsamında göstergebilimsel olarak incelenmiştir.

Yapılan çalışmada görsellerin düz anlamlarının yanında yan anlamlarına da odaklanılmış; resimlerin sadece bir tablo olarak süsleme işlevini yerine getirmekle kalmayıp menkabeden dünya görüşüne, düşünce yapısından inanışlara varıncaya kadar birçok konuya ilişkin atıflar, hatırlatmalar, göndermeler taşıdıkları görülmüştür. Kırmızı ve yeşil sadece birer renk olarak değil Hz. Hasan'ın zehirle (yeşil), Hz. Hüseyin'in kılıçla başı kesilerek 
(kırmızı) şehit edilmelerini hatırlatmaktadır. Zülfikâr yalnızca kılıç değil adaletin, Hz. Ali'nin yiğitliğinin ve doğruluğunun simgesidir. Aslan yiğitliğin, korkusuzluğun sembolüdür. Hz. ỉbrahim'in oğlunu kurban edişinin resmedildiği tablo kulun teslimiyetini, Cebrail'in koç indirmesi ilahi yardımın göstergesidir. Tüm bu göstergeler bütün olarak değerlendirildiğinde söz konusu görsellerin yer aldığı mekânın dinî nitelikli bir mekân olduğunu göstermektedir. Çalışma neticesinde cemevinde yer alan görsellerin mekâna kimlik kazandırarak, bilinçli bir şekilde oraya gelen bireylerin kendi kimliklerini tanımlayıp yansıtmalarına ve kendilerini mekâna ait hissetmelerine katkı sağlayacak bir işlevi yerine getirdiği görülmüştür. Buradan hareketle Türk halk resminin görsel göstergeler olarak cemevi özelinde işlevlerini sürdürdüğü söylenebilir.

\section{Kaynakça}

Aksel, Malik (2010). Türklerde Dinî Resimler. Haz. Beşir Ayvazoğlu. İstanbul: Kapı Yayınları.

Aslanapa, Oktay (1972). Türk Sanatı 1-2. İstanbul: Milli Eğitim Bakanlığı Yayınları.

Barthes, Roland (1993). Göstergebilimsel Serüven. Çev. Mehmet Rifat ve Sema Rifat. İstanbul: Yapı Kredi Yayınları.

Başkan Karsak, Banu (2004). "Görsel Kimlik Göstergeleri Açısından 'Arçelik' Firması Web Sayfası İncelemesi”. Galatasaray Üniversitesi iletişim Dergisi, 1: 99-114.

Dalbay, Ramazan Saim (2018). "Kimlik ve Toplumsal Kimlik Kavramı”. Süleyman Demirel Üniversitesi Sosyal Bilimler Enstitüsü Dergisi, 31: 161176.

Gözübüyük Tamer, Mine (2014). "Kimlik/lerin Seyrine Bir Keşif”. Folklor/Edebiyat, 20(77): 83-99.

Günay, V. Doğan (2002). Göstergebilim Yazıları. İstanbul: Multilingual Yayınları.

Günay, V. Doğan ve Parsa, Alev F. (2012). Görsel Göstergebilim: Imgenin Anlamlandırılması. İstanbul: Es Yayınları.

Günşen, Ahmet (2007). "Gizli Dil Açısından Alevilik-Bektaşilik Erkân ve Deyimlerine Bir Bakış”. Turkish Studies/Türkoloji Araştırmaları, 2(2): 328351. 
Kocadağ, Burhan (1998). Şahkulu Sultan Dergâhı ve istanbul Bektaşi Tekkeleri. İstanbul: Can Yayınları.

Öz, Mustafa (2013). "Zülfikar”. İslam Ansiklopedisi, C. 44. İstanbul: Türkiye Diyanet Vakfı, 553-554.

Özgüleş, Muzaffer (2019). "Bireyden Cemaate Geçişte Mekânın Rolü: Aidiyet Simgesi Yapılar”. Mekânlar/Zamanlar/Insanlar. Kimlik, Aidiyet ve Mimarlık Tarihi. Der. Çağla Caner Yüksel ve Ceren Katipoğlu Özmen. Ankara: ODTÜ Basım İşliği, 33-45.

Parsa, Seyide (1999). "Televizyon Göstergebilimi”. Kurgu Dergisi, 16: 15-28.

Rençber, Fevzi (2012). “Alevi Geleneğinde 'Cem Evinin' Tarihsel Kökeni”. Dinbilimleri Akademik Araştırma Dergisi, 12(3): 73-86.

Rifat, Mehmet (2014). Göstergebilimin ABC'si. İstanbul: Say Yayıncılık.

Sarıkaya, Meliha Y. (2013). "Zülfikar". İslam Ansiklopedisi, C. 44. İstanbul: Türkiye Diyanet Vakfı, 554-556.

Şentürk, Aylin ve Gülersoy, Nuran Zeren (2019). “Aidiyet, Kent Kimliği ve Kentsel Koruma Etkileşimi Bağlamında Kullanıcı Sürekliliğinin İrdelenmesi: Kadıköy Moda Örneği”. MEGARON, 14(1): 145-159.

Turut, Hatice ve Özgür, E. Murat (2018). "Bir Kente Göçün Hikâyesi: Süreçler, Bütünleşme ve Aidiyet”. Coğrafi Bilimler Dergisi, 16(1): 153-180.

URL-1: "Tarihçe". https://karacaahmet.org.tr/kurumsal/1/tarihce. (Erişim tarihi: 15.08 .2020$)$.

Üçer, Cenksu (2018). “Cemevi: Adab ve Erkânın İcra Edildiği Mekân”. Türk Kültürü ve Hacı Bektaş Veli Araştırma Dergisi, 88: 59-84.

Yaman, Mehmet (2008). Karacaahmet Sultan. İstanbul: Karacaahmet Sultan Kültür Derneği, 103-105.

Yıldırım, Erdal (2018). “W. Isaac Thomas'ın 'Durum Tanımlaması' Kavramı Bağlamında Alevilerin Cemevi Meselesi Durumunun Ortaya Konulması". Alevilik Araştırmaları Dergisi, 15: 47-52.

Yılmaz, Seval (2011). Türkiye'de Cemevleri Kurumsallaşmasının Alevi Kimliğine Etkileri ve Karacaahmet Sultan Dergâhı Üzerinden Bir Alan Analizi. Yüksek Lisans Tezi. İstanbul: Yıldız Teknik Üniversitesi Sosyal Bilimler Enstitüsü. 
“COPE-Dergi Editörleri İçin Davranış Kuralları ve En İi Uygulama ilkeleri” çerçevesinde aşağıdaki beyanlara yer verilmiştir:

Yazarın Notu: Makalede yer alan görsellerin Karacaahmet Cemevi yönetiminden yazıı izin alınarak tarafımca çekilmiş fotoğraflar olduklarını beyan ederim.

İzinler ve Etik Kurul Belgesi: Bu çalışma için etik kurul belgesi gerekmemektedir. Makalede kullanılan fotoğrafların çekimi için Karacaahmet Cemevi yönetiminden 05.03.2021 tarihinde yazılı izin alınmış ve bu izin belgesi editörlüğe gönderilmiştir.

Çıkar Çatışması Beyanı: Bu makalenin araştırması, yazarlığı veya yayınlanmasıyla ilgili olarak yazarın potansiyel bir çıkar çatışması yoktur.

The following statements are made in the framework of "COPE-Code of Conduct and Best Practices Guidelines for Journal Editors":

Author's Note: I declare that the images in the article are photographs taken by me with written permission from the directors of Karacaahmet Cemevi.

Permissions and Ethics Committee Approval: Ethics committee approval is not required for this study. A written permit was obtained from the management of Karacaahmet Cemevi on 05.03.2021 for the photographs used in the article and this permit was sent to the editor.

Declaration of Conflicting Interests: The author has no potential conflict of interest regarding research, authorship or publication of this article. 